\title{
Late quaternary dynamics in the Madeira river basin, southern Amazonia (Brazil), as revealed by paleomorphological analysis
}

\author{
ERICSON H. HAYAKAWA ${ }^{1}$ and DILCE F. ROSSETTI ${ }^{2}$ \\ ${ }^{1}$ Universidade Estadual do Oeste do Paraná - Unioeste/GEA, Rua Pernambuco, \\ 1777, Centro, 85960-000 Marechal Cândido Rondon, PR, Brasil \\ ${ }^{2}$ Instituto Nacional de Pesquisas Espaciais / INPE, Observação da Terra - \\ Divisão de Sensoriamento Remoto (OBT/DSR), Rua dos Astronautas, 1758, \\ Caixa Postal 515, Jardim da Granja, 12245-970 São José dos Campos, SP, Brasil
}

Manuscript received on December 9, 2013; accepted for publication on April 7, 2014

\begin{abstract}
Ancient drainage systems are being increasingly documented in the Amazon basin and their characterization is crucial for reconstructing fluvial evolution in this area. Fluvial morphologies, including elongate belts, are well preserved along the Madeira River. Digital Elevation Model from the Shuttle Radar Topography Mission favored the detection of these features even where they are covered by dense rainforest. These paleomorphologies are attributed to the shifting position of past tributaries of the Madeira River through avulsions. These radial paleodrainage networks produced fan-shaped morphologies that resemble distributary megafans. Distinguishing avulsive tributary systems from distributary megafans in the sedimentary record is challenging. Madeira's paleodrainage reveals the superposition of tributary channels formed by multiple avulsions within a given time period, rather than downstream bifurcation of coexisting channels. Channel avulsion in this Amazonian area during the late Quaternary is related to tectonics due to features as: (i) straight lineaments coincident with fault directions; (ii) northeastward tilting of the terrain with Quaternary strata; and (iii) several drainage anomalies, including frequent orthogonal drainage inflections. These characteristics altogether lead to propose that the radial paleodrainage present at the Madeira River margin results from successive avulsions of tributary channels over time due to tectonics.
\end{abstract}

Key words: paleochannels, Amazon Basin, Madeira river, remote sensing, climate, tectonics.

\section{INTRODUCTION}

Large tropical river systems are increasingly being investigated (see numerous references in Latrubesse et al. 2005) chiefly because of the interest in understanding their origin and evolution, as well to establish models that help recognize ancient analogs. Of all modern megariver systems, the Amazon is the largest one, with a drainage

Correspondence to: Dilce de Fátima Rossetti

E-mail: rossetti@dsr.inpe.br area of $6,000\left(10^{3} \mathrm{~km}^{2}\right)$, mean annual discharge of $209,000 \mathrm{~m}^{3} \mathrm{~s}^{-1}$, and sediment load of 167 tons $\mathrm{km}^{-2}$ year $^{-1}$. Numerous studies have emphasized the hydrological, sedimentological, geochemical and morphological characteristics of this fluvial system (e.g., Gibbs 1967, Sioli 1984, Franzinelli and Igreja 2002, Mertes and Dunne 2007, Latrubesse 2008). Moreover, several studies have contributed to describe ancient drainage systems in Amazonia with emphasis on paleoclimate (e.g., Latrubesse 
and Ramonell 1994, Müller et al. 1995, Latrubesse 2002), tectonics (Sternberg 1950, Iriondo and Suguio 1981, Souza Filho et al. 1999, Latrubesse and Rancy 2000, Costa et al. 2001) and sea-level changes (Irion 1984, Vital and Stattegger 2000) during the late Quaternary.

Further efforts are still needed in order to create a larger database before a consensus can be reached concerning the understanding of the main factors that have controlled the origin and evolution of Amazonian rivers. The reconstruction of paleomorphologies still preserved on the Amazonian landscape can contribute to reach this goal. The right margin of the Madeira River, one of the main Amazon tributaries, is an area of special interest for this investigation because it contains an abundance of morphologies related to ancient drainage networks (Mauro et al. 1978, Latrubesse 2002). The latter author, based on the analysis of Landsat and radar images, considered this ancient drainage as part of a megafan depositional system developed in the Amazonian landscape as a result of dry climates during the Last Glacial Maximum.

The definition of a megafan, as used in this work, has been debated in the literature and alternative terms such as fluvial fan or terminal fan have also been proposed (see Nichols and Fisher 2007, North and Warwick 2007 for a review). In general, descriptions of ancient megafans are rare, with a few analogs being the Luna of the Ebro Basin in Spain (Friend 1989, Stanistreet and McCarthy 1993, Nichols and Fisher 2007), the Devonian deposits of the Munster Basin in Ireland (Williams 2000), and the Wood Bay Formation of the Bay of Spitsbergen in England (Friend and Moody-Stuart 1972). Additionally, the existence of several, either continuous or discontinuous megafans, has been proposed along the Andean Chain as a result of mountain uplift in the northern ranges during the Miocene (e.g., Wilkinson et al. 2010, see also Leier et al. 2005, Hartley et al. 2010, Weissmann et al. 2010).
The widespread recognition of megafans in the geological record has been precluded by the lack of criteria to distinguish megafan lithofacies from typical fluvial lithofacies. The characterization of megafans is challenging even in modern settings. This is mainly due to their large dimensions that make it difficult to obtain a complete view of the entire system, as well as the deficient understanding of their sedimentary processes. As a consequence, descriptions of ancient and modern megafans are still incomplete, with the majority of the information being related to megafans of the Okavango in South Africa (Stanistreet and McCarthy 1993, Gumbricht et al. 2001), the Kosi, Gandak and Tista of the Gangean-Brahmaputra region (Sinha et al. 2005, Chakraborty et al. 2010) and the Taquari in Brazil (Assine 2005).

Due to the large dimensions of megafans, remote sensing has been the main tool used to characterize them in modern and Quaternary settings. Digital Elevation Model (DEM) derived from the Shuttle Radar Topography Mission (SRTM), represent a new opportunity for improving the record of paleomorphologies in areas of dense forest, such as the Amazonian rainforest (e.g., Rossetti 2010). Previous publications have demonstrated the usefulness of this tool for the detection of many paleodrainage systems in the region (Almeida Filho and Miranda 2007, Rossetti and Valeriano 2007, Silva et al. 2007, Mantelli et al. 2009, Hayakawa et al. 2010, Bertani et al. 2013).

The work presented here combines DEMSRTM and optical images to improve the detection of paleodrainage networks at the right margin of the Madeira River. These new data are invaluable to: (i) reconstruct channel dynamics over time; (ii) reassess their potential relation with megafan systems; and (iii) discuss their significance for analyzing the main factors that controlled channel migration and abandonment in this Amazonian lowland.

\section{STUDY AREA}

The study area is located on the right margin of the Madeira River and encompasses the Aripuanã- 
Madeira interfluve and both margins of the Jiparaná River (Fig. 1A). This area is located approximately $300 \mathrm{~km}$ south to southwest of the city of Manaus in the State of Amazonas, and the second area is located $150 \mathrm{~km}$ northeastward of the city of Porto Velho in the State of Rondonia.

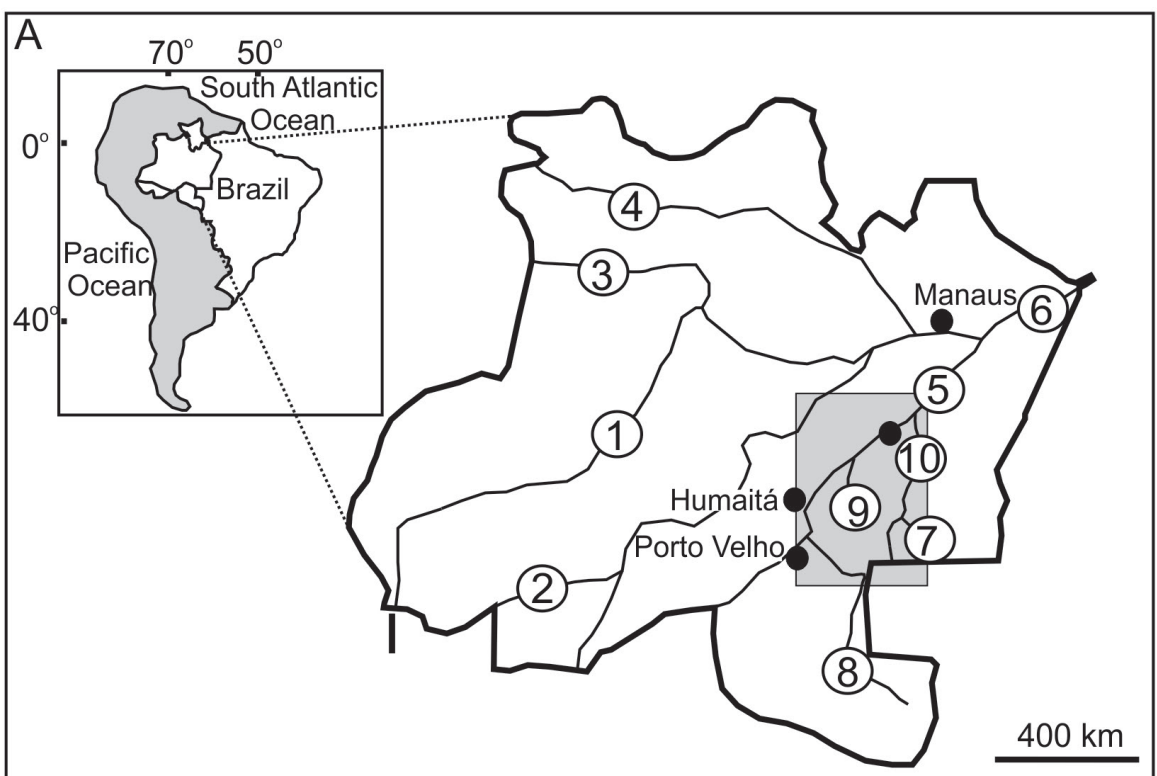

\section{$\triangle$ Study area \\ Main locality \\ River}

1 Juruá River

2 Purús River

3 Solimões River

4 Negro River

5 Madeira River

6 Amazonas River

7 Aripuanã River

8 Jiparaná River

9 Marmelos River

10 Manicoré River

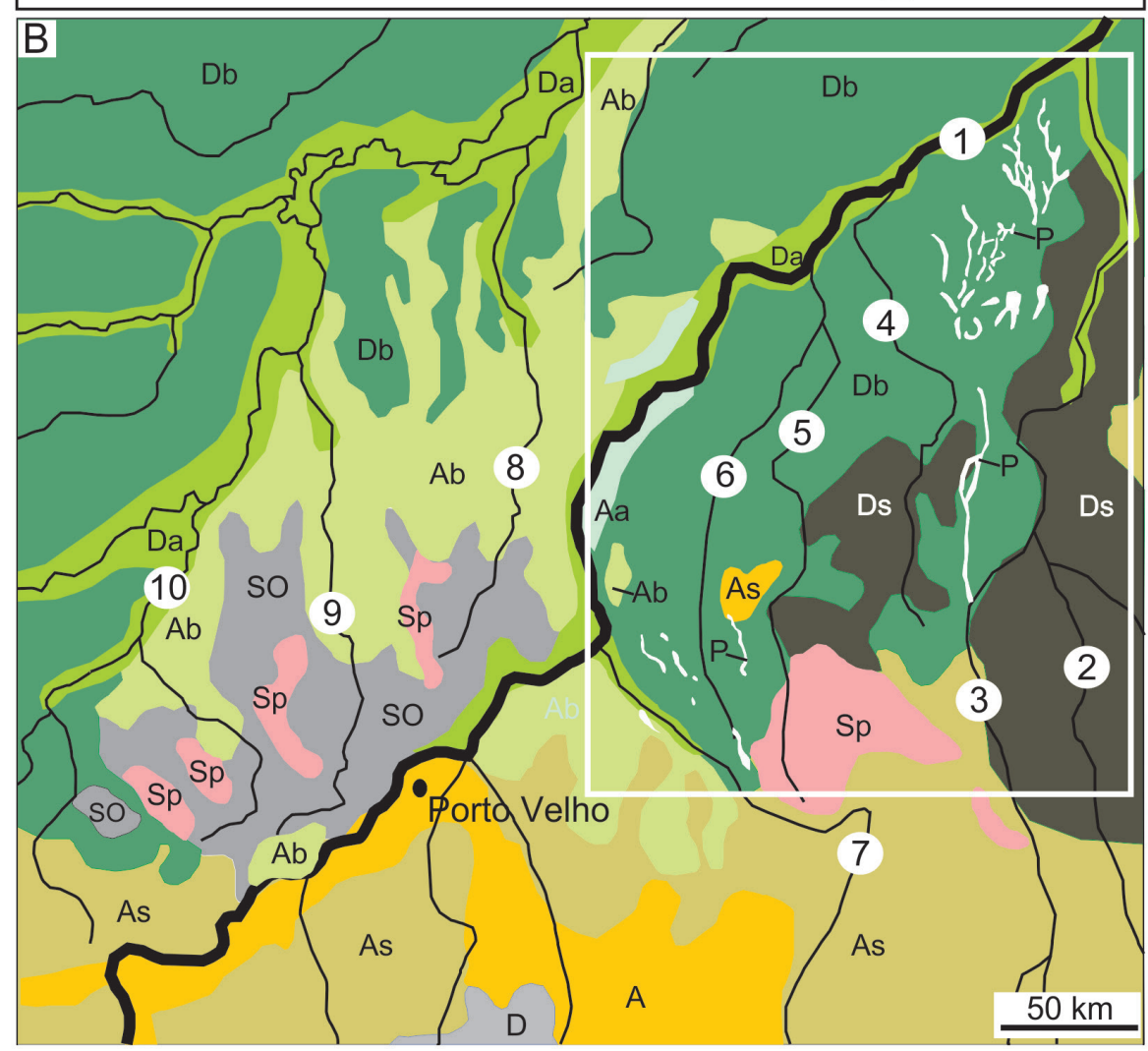

Ombrophyla dense forest

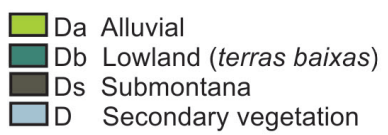

A Ombrophyla open forest

Aa Alluvial

Ab Lowland (terras baixas)

As Submontana

A Secondary vegetation

Sp Savanna

$\square$ P Pioneer vegetation (Grass and shrub)

So Contact of Savannal Ombrophyla forest

1 - Madeira River

2 - Aripuanã River

3 - Roosevelt River

4 - Manicoré River

5 - Marmelos River

6 - Maici River

7 - Jiparaná River

8 - Ipixuna River

9 - Mucuim River

10 - Ituxi River

Figure 1 - A) Location of the study area and main rivers in Central Amazonia. B) Vegetation map of the study area (rectangle) and its surroundings. The elongated areas of pioneer formations correspond to some of the paleomorphologies emphasized in this work. (Vegetation classes according to Mauro et al. 1978). 
The climate is tropical, with a short dry season (Am in Köppen's classification), mean annual temperature of $28{ }^{\circ} \mathrm{C}$, and mean annual precipitation of 2,500 to $3,000 \mathrm{~mm} \mathrm{year}^{-1}$. The rainy season begins in October, with precipitation peaking between January and February and a dry period between June and August. The topography is flat, with SRTM elevation between 150 and $60 \mathrm{~m}$. The region is dominated by latosols and, secondarily, podzols (Mauro et al. 1978), and vegetation cover is mostly dense lowland ombrophilous forest, including non-flooded upland and seasonally flooded varzea/gallery forests, with narrow strings of pioneer (grassy and bushy) vegetation (Fig. 1B).
Geologically, the study area lies within the southwestern and southeastern parts of the Amazonas and Solimões sedimentary basins, respectively (Fig. 2). The former, an intracratonic rift due to Early Paleozoic intraplate extension, covers up to 515,000 $\mathrm{km}^{2}$. The latter, encompassing $440,000 \mathrm{~km}^{2}$, is a foreland basin also formed by intraplate extension, but combined with deformation during the rise of the Andean Chain in the Cretaceous and Cenozoic (Apoluceno Neto and Tsubone 1988). These basins, separated by the Purus Arch, are bounded by the Guiana Shield to the north and the Central Brazil Shield to the south. The Gurupá and Iquitos Arches separate the Amazonas and Solimões basins from the Marajó Graben System and Acre Basin, respectively.

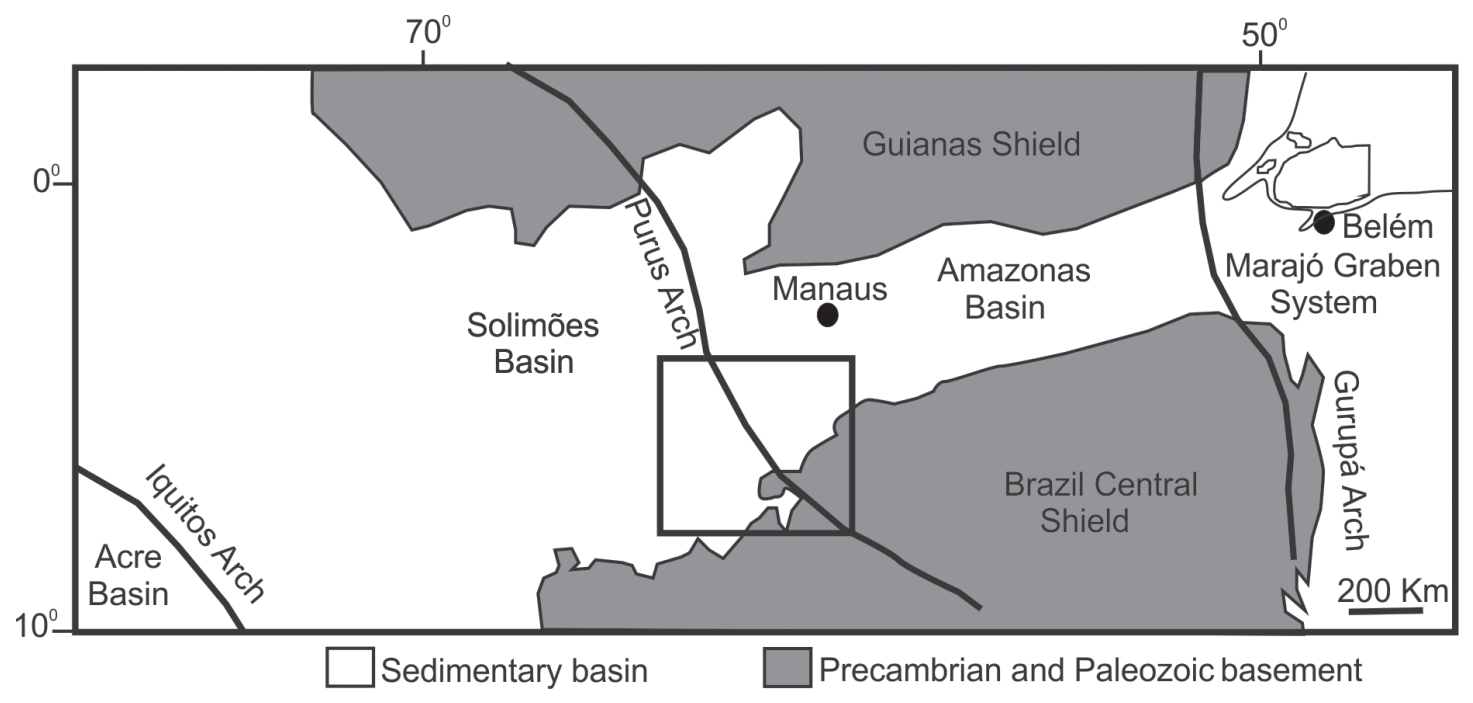

Figure 2 - Limits of the Amazonas and Solimões Basins, where the study area (inside box) is located (modified from Caputo and Silva 1990).

The Amazonas and Solimões basins were developed over igneous, metamorphic and volcanosedimentary Precambrian basement rocks (Teixeira et al. 1989). Deposition in these basins was initiated in the Proterozoic and continued in the Paleozoic. The sedimentary fill of the Amazonas Basin consists of several geological units formed during the OrdovicianEarly Devonian, Devonian-Early Carboniferous, and Middle Carboniferous-Permian. The main phase of sediment accumulation in the Solimões
Basin occurred between the mid Devonian and the Permian. Sediment deposition was reactivated during the Cretaceous and Cenozoic. Cretaceous deposits, represented in both basins, consist of the Alter do Chão Formation, which includes red sandstone, mudstone, conglomerate and intraformational breccia related to fluvial, lacustrine (Daemon 1975), and deltaic depositional systems (Rossetti and Netto 2006). The Cenozoic deposits, which occur mainly in the Solimões Basin, include the Miocene Solimões 
and the Plio-Pleistocene Içá Formations (Cunha et al. 1994), as well as several unnamed PleistoceneHolocene deposits (Rossetti et al. 2005). The Solimões Formation (Miocene) consists of shales and sandstones formed in lacustrine to transitional marine settings (e.g., Monsch 1998, Wesslingh et al. 2001). Plio-Pleistocene to Holocene deposits occupy a large portion of the western Amazonas Basin and are represented by the Içá Formation, as well as other unnamed Quaternary successions. The Içá Formation is characterized by non-fossiliferous sandstones, subarkoses and, to a lesser extent, mudstones formed mainly in braided river systems (Rossetti et al. 2005). The Quaternary deposits, unconformable with underlying units, are particularly well developed west of the city of Manaus (Rossetti et al. 2005, E.A.A. Soares, unpublished data). At the surface, the area containing the paleomorphologies emphasized here contains Late Pleistocene deposits that intercept older Pleistocene strata of the Içá Formation (Fig. 3A). In addition, Proterozoic crystalline rocks bound these deposits to the south and southeast.
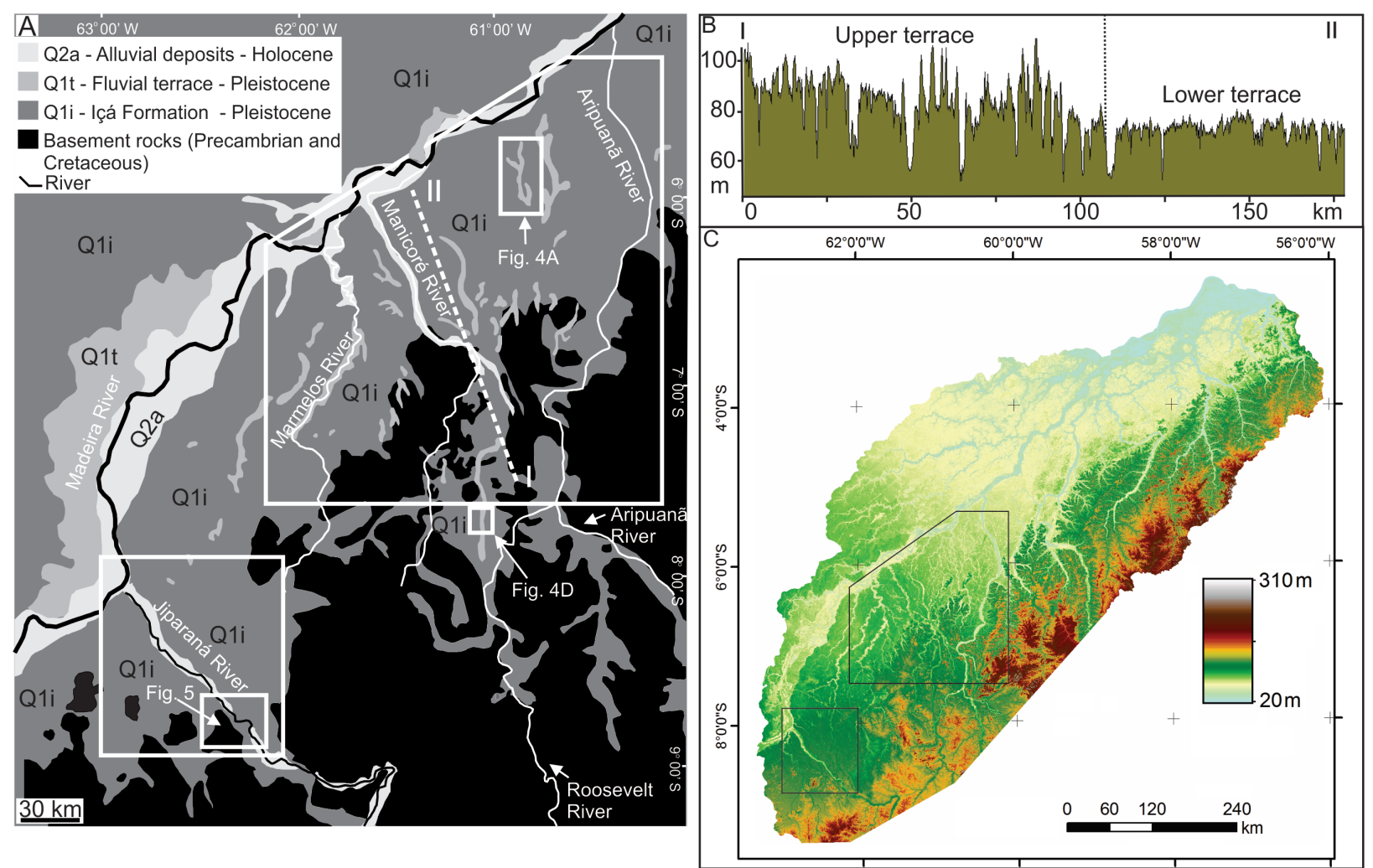

Figure 3 - A) Simplified geological map of the study area and its surroundings, with the Aripuanã-Marmelos and Jiparaná areas indicated by rectangles (dashed line I-II indicates the position of a topographic profile derived from DEM-SRTM shown in B). B) DEM-SRTM topographic profile (see location in A) illustrating the upper and lower terrains in the Aripuanã-Marmelos area. C) Hypsometic map of the study area and its surroundings. (Black polygons = study areas).

\section{MATERIALS AND METHODS}

The data used in this research consist of freely accessed remote sensing products including Landsat 5-TM images (access on $<$ www.dgi.inpe. br $>$ ), DEM-SRTM data (access on ftp://e0srp01u. ecs.nasa.gov/srtm/), optical images derived from Google Earth ${ }^{\mathrm{TM}}$, geologic and geomorphologic data available in the literature, and modern drainage network (scale 1:100 000) available in shapefile format from the Ministério do Meio 
Ambiente (http://mapas.mma.gov.br/mapas/aplic/ cartoamazonia/). Landsat 5-TM images from the year 2000 were selected based on low cloudcover and their correspondence with the time when the SRTM flight took place. These images were registered, processed for R (red) G (green) B (blue) band composition, and integrated with the drainage network. Several band compositions were performed, with the 5(R), 4(G) and 3(B) providing the best view of the features characterized herein.

The DEM-SRTM data derive from the original 90-m resolution (3 arc seconds) C-Band synthetic aperture radar data acquired by the National Aeronautics and Space Administration (NASA), National Imagery and Mapping Agency (NIMA), DLR (German Space Agency), and ASI (Italian Space Agency), aboard the spaceship Endeavour in February 2000. The data, downloaded from the site http://edc.usgs.gov/srtm/data/obtainingdata. html, are unprojected, with geographic coordinates as reference units and WGS84 as the reference ellipsoid and datum. Elevation is expressed in meters. Original DEM-SRTM presents data failure such as negative elevation values, especially in areas of lakes and rivers. This was corrected using the Topography tool in the ENVI software for replacing bad values. The DEM-SRTM data were processed using customized shading schemes and palettes (cf. Rossetti and Valeriano 2007, Mantelli et al. 2009, Hayakawa et al. 2010) using the Global Mapper software. This procedure was particularly useful for highlighting the morphological features of interest for this research according to on-screen observations. The morphology was also revealed by roughness from the DEM, which helped highlight different rocks and deposits. The SRTM topographic profiles were useful in detecting relief configuration and the main features and forms. Integration of these data with available geological and geomorphological data helped characterize and analyze the paleomorphologies of the study area.
The analysis of morphostructural lineaments was based on geological maps provided by the Brazilian Institute of Geography (IBGE), with vector adjustments based on the analysis of remote sensing products. The beeter characterization of morphostructural lineaments consisted of visual interpretation and manual vectorization based on 1:100 000 modern drainage network. Optical images improved the identification of morphostructural lineaments. Vectorization and diagrams of absolute frequency and length frequency were developed in the SRING 4.3.3. software. The identification of drainage anomalies was based on visual interpretation of remote sensing data integrated with the modern drainage network as suggested in the literature (e.g., Howard 1967, Schumm et al. 2000). Google Earth ${ }^{\mathrm{TM}}$ images were used to analyze the features of interest in more detail.

\section{MORPHOLOGICAL DESCRIPTION}

The study area occurs in two terrains (Fig. 3A-C). The first is an area to the southeast with altitudes between 100 and $150 \mathrm{~m}$. Precambrian to Cretaceous rocks dominate in this area, with Quaternary deposits occurring only along river valleys. The second area to the northwest displays altitudes ranging from 60 to $100 \mathrm{~m}$ and contains only Quaternary deposits. The contact between these terrains is sharp and consists of several straight segments which define main NE-trending morphostructural lineaments. Paleodrainage morphologies are recorded by numerous narrow, but elongated belts that range from straight to highly sinuous, similarly to the morphology of many modern fluvial channels (Fig. 4A-F). The paleomorphologies are either continuous or discontinuous, the latter consisting of sets of segments promptly reconstructed as paleochannel fragments. In optical images, these landforms are only detected where highlighted by pioneer vegetation and/or bare soil in sharp contact with adjacent areas of dense forest (Fig. 4A-C). In addition, SPOT images revealed that parts of 
the paleochannels are covered by sand dunes (Fig. 3D-E). Interestingly, tree species from forested areas adjacent to the belts are gradually advancing toward the paleochannel areas (Fig. 4F). In contrast to optical images, DEM-SRTM provided a much more complete view of the studied paleomorphologies, particularly those hidden under the dense rainforest (Fig. 5A-B).
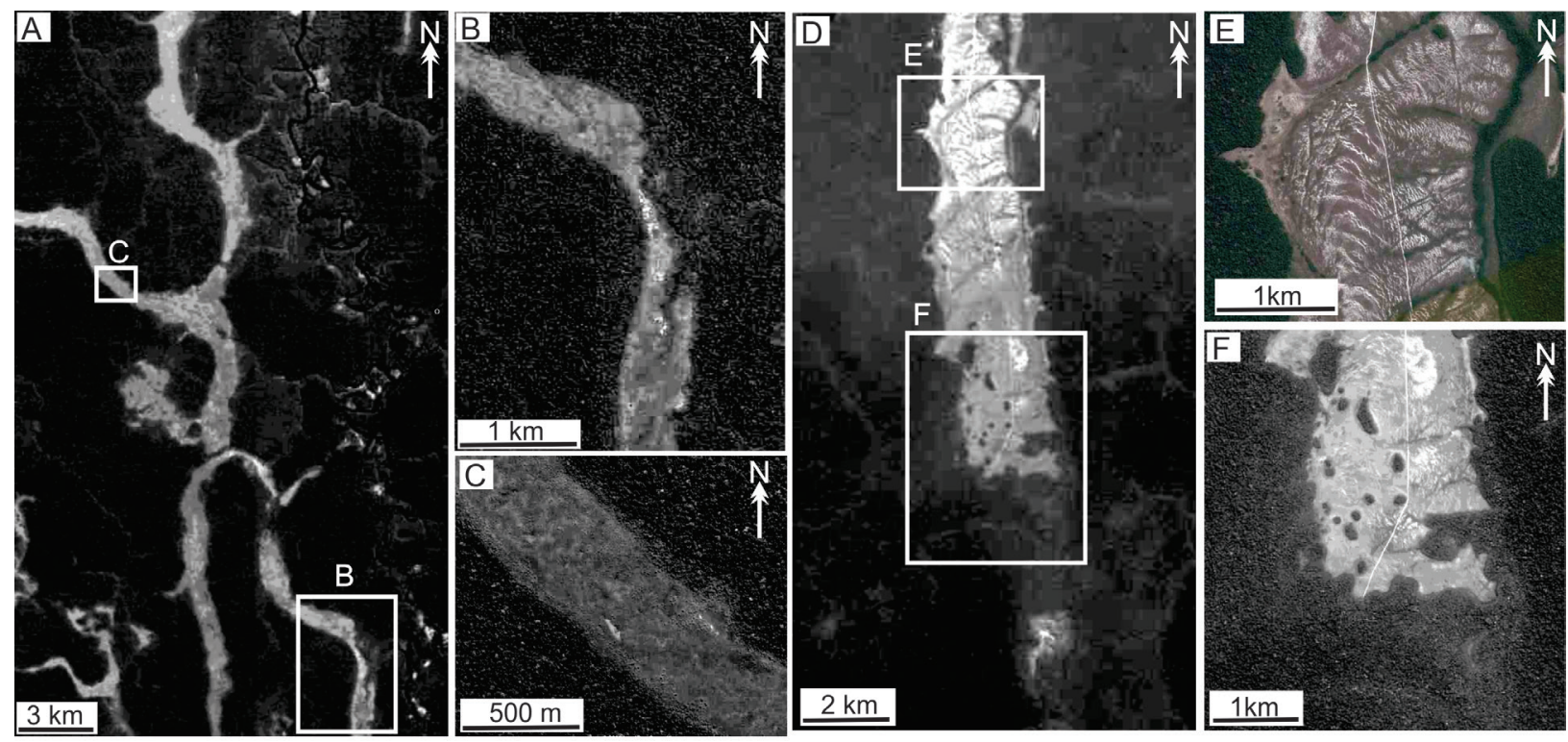

Figure 4 - Characteristics of the paleochannels in the study area. A) SPOT image (Google Earth ${ }^{\mathrm{TM}}$ ) illustrating the sharp contact between pioneer formations over paleochannel areas and ombrophylous forest in their surroundings (inside boxes identify $\mathbf{B}$ and $\mathbf{C}$ ). B,C) SPOT images (Google Earth ${ }^{\mathrm{TM}}$ ) with details of the paleochannels shown in A. D-F) General view (D) and details (E and F) of a paleochannel covered by sand dunes (light tones) in sharp contact with ombrophylous forest (dark tones). Note in $\mathbf{D}$ and $\mathbf{F}$ that the paleochannels are partly covered by forest (light tones in $\mathbf{A}$ to $\mathbf{C}=$ paleochannel with pioneer formations; dark tones in $\mathbf{A}$ to $\mathbf{C}=$ ombrophylous forest). (See location of $\mathbf{A}$ and $\mathbf{D}$ in Fig. 3).

The paleomorphologies in the study area can be described as two paleochannel sets, one located between the Aripuanã and Marmelos Rivers, and the other located in the lowest reaches of the Jiparaná River near its confluence with the Madeira River (Fig. 3A). Paleochannels in the Aripuanã-Marmelos interfluve are the largest ones and consist of an intricated drainage network that spreads out over an area up to $30,000 \mathrm{~km}^{2}$ (Figs. 6, 7A-C). These paleomorphologies occur in both the highest and the lowest terrains, although they are more widespread in the latter. The topography in the lowest terrain generally varies slightly between 80 and $60 \mathrm{~m}$ northeastward (Fig. 3B). The dimension of individual paleochannels varies, with lengths up to $250 \mathrm{~km}$ and widths up to $3.5 \mathrm{~km}$. The largest paleochannels occur in the center of this area (Figs. 6, 7A). They form segments that either intercept laterally adjacent paleochannels or are arranged as interconnecting branches. There are downstream convergences to the northwest, north and northeast and paleochannel superposition is common. A striking characteristic in the central part of the study area is an assemblage of northwestward to northeastward trending dendritic paleodrainage composed of large (i.e., averaging $2.5 \mathrm{~km}$ in width) paleochannels covered by pioneer vegetation. These paleochannels abruptly taper downstream, as they converge into single and highly sinuous paleochannels that are in continuity with active channels (Fig. 7B). It is interesting that these changes occur right at the boundary between the 

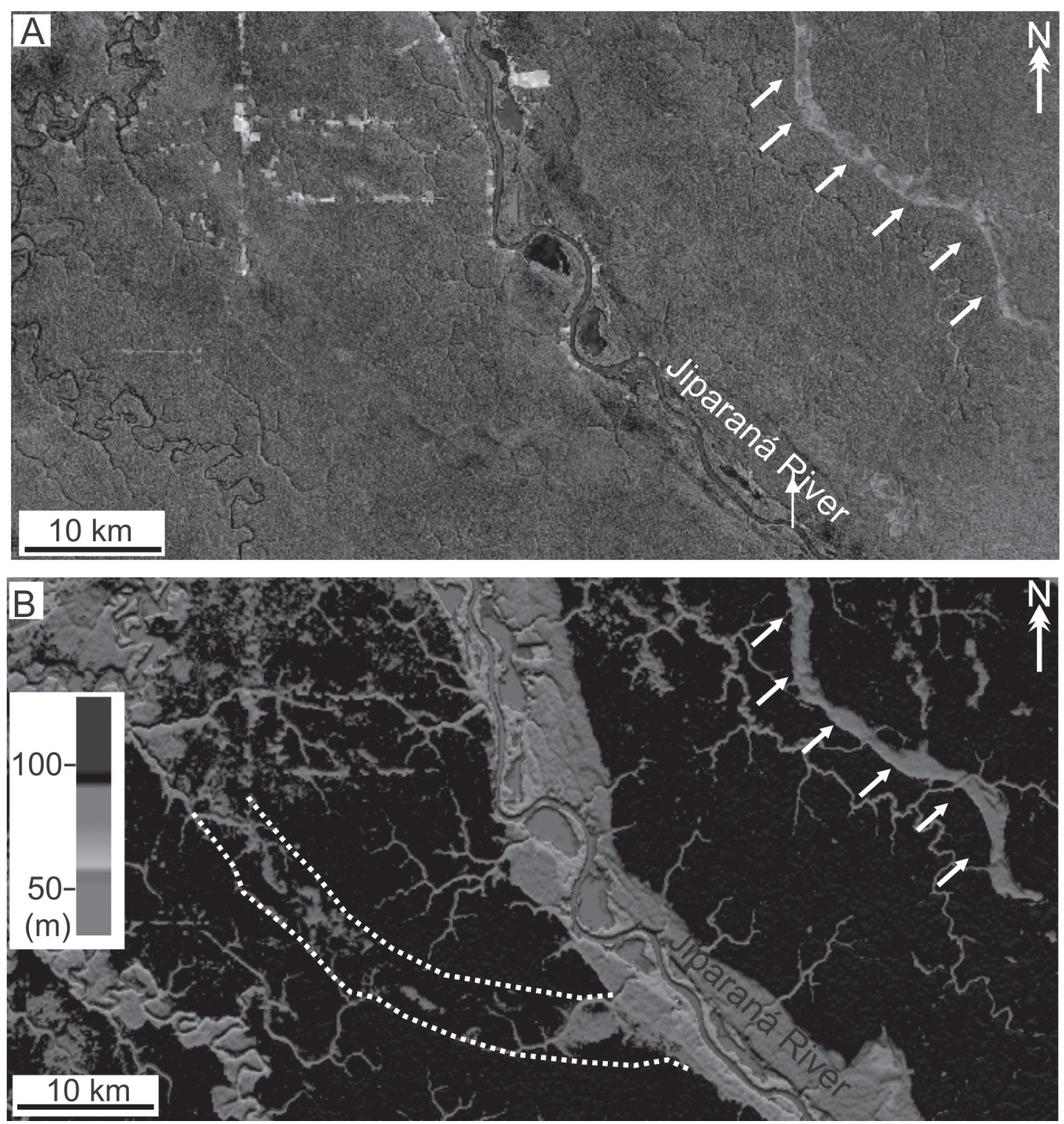

Figure 5 - A-B) Views of paleochannels comparing Landsat images (A) with the DEM-SRTM (B). Paleochannels covered by pioneer formations (arrows) are seen on both products, while paleochannels covered by dense ombrophylous forest are barely visible in the Landsat image, but can easily be traced in the DEM-SRTM product (dashed line in B). (See location in Fig. 3).

previously described highest and lowest terrains. Also remarkable is that the channels have orthogonal inflections at this boundary, and deviate to the right to follow the straight NE-trending lineaments between the two topographic terrains (Fig. 7B). Another important morphological observation is that the main paleochannels in this area are physically connected to the modern
Aripuanã River at several locations (Figs. 7A and C). The connection of the main paleochannel in the central part of this area occurs where the Aripuanã River develops an anomalously wide loop (Fig. 6).

The Jiparaná River paleomorphologies are less extensive than the ones in the AripuanãMarmelos area, encompassing less than $8,500 \mathrm{~km}^{2}$ (Fig. 8A-C). However, similarly to that area, most 


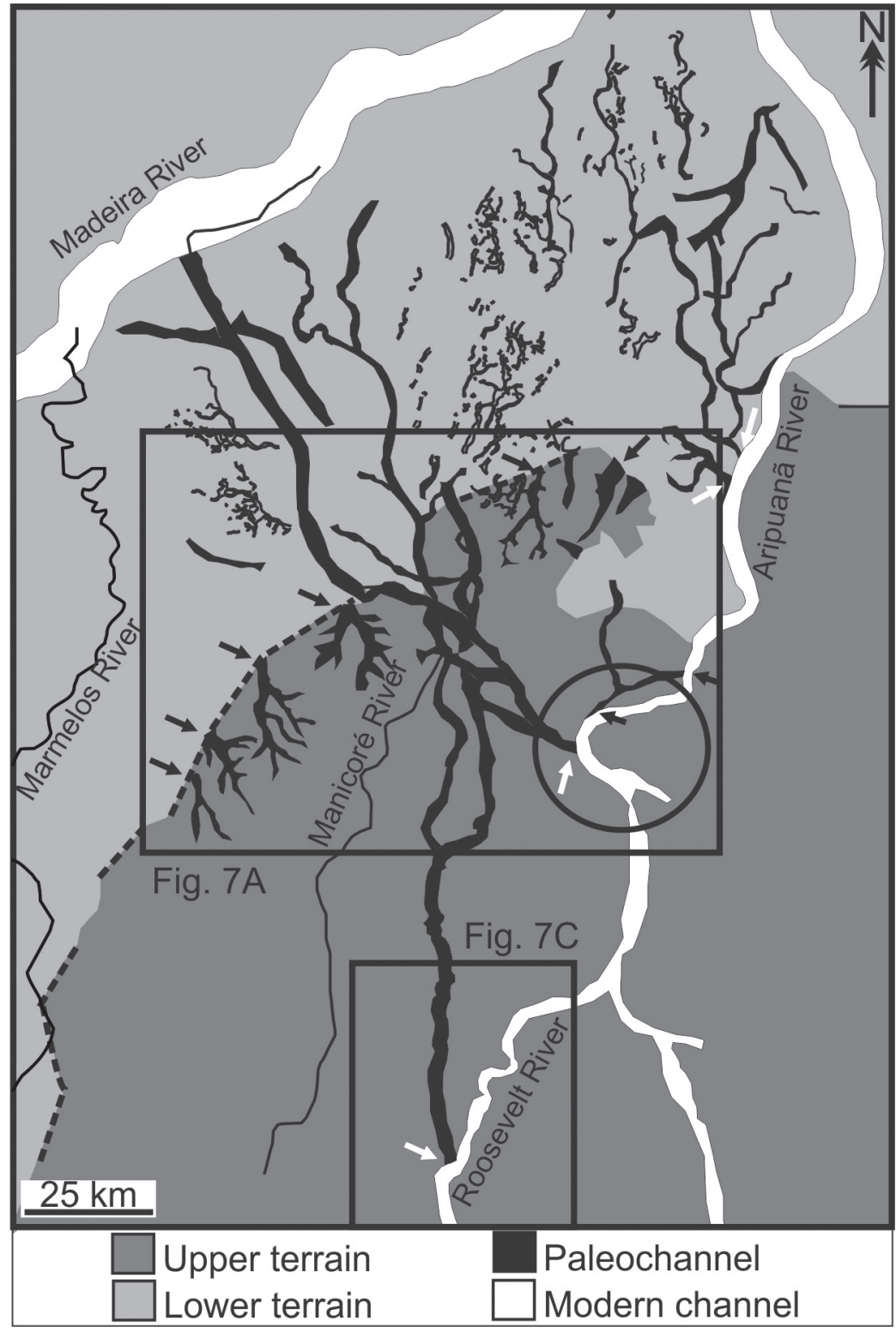

Figure 6 - Paleomorphogies and the distribution of the highest and lowest terrain in the Aripuanã-Marmelos interfluve. Note the sharp contact between the higher and lower terrain (black arrows), defined by straight NE-SW trending morphostructural lineaments (dashed lines). Observe also the termination of several dentritic northwestward flowing paleochannels at this boundary and the many locations where a paleochannel joins with the Aripuanã River (white arrows). (circle = anomalous meander of the Aripuanã River).

of the Jiparaná paleochannels are concentrated in the lower terrain (Fig. 8D). Transverse DEMSRTM topographic profiles generally do not reveal any significant altitudinal gradients, although an overall northeastward topographic variation from
90 to $100 \mathrm{~m}$ occurs near the Madeira River. The contact between the topographically lower and higher terrains in the Jiparaná area is also sharp, being defined by major straight and orthogonal, NW-SE to NE-SW trending lineaments (Fig. 8A). 

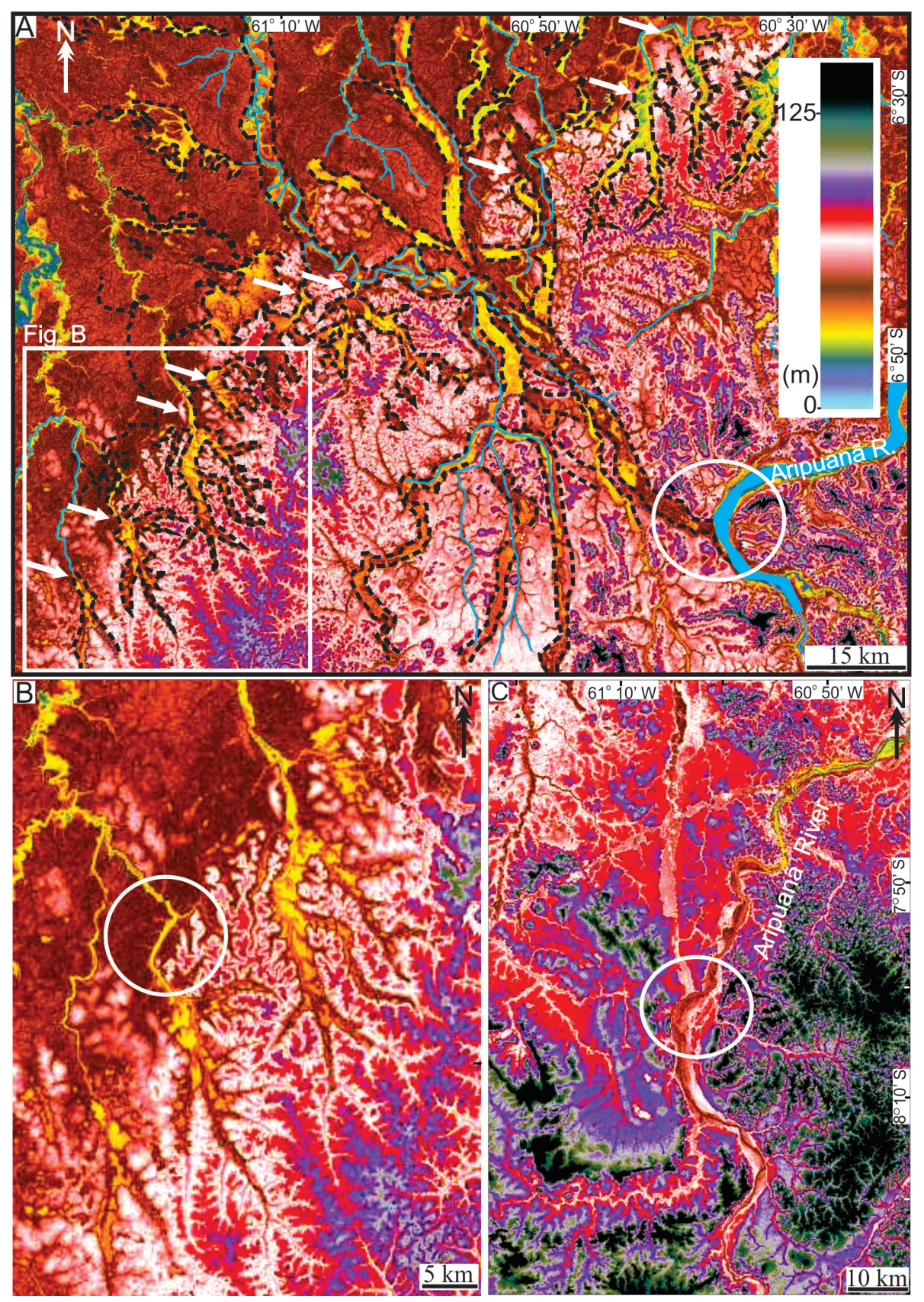

Figure 7 - DEM-SRTM illustrating details of paleochannels in the central part of AripuanãMarmelos area. A) General view of intricate paleochannels (dotted lines) superposed upon one another. Observe the paleochannels that terminate (arrows) at the boundary between the higher and the lower terrain. (blue lines = main modern channels; inside rectangle locates B; circle $=$ a main paleochannel that joins an anomalous meander of Aripuanã River ). B) Detail of A, illustrating three of the paleochannels that end at the boundary between the higher and lower terrains. Note that a modern northwestward flowing channel associated with one of these paleochannels locally inflects to the northeast and then back to the northwest, configuring orthogonal angles (circle). C) Detail of the paleochannel that are intercepted by the Aripuanã River where it configures an anomalous meander in the southern part of this area. (See location of $\mathbf{A}$ and $\mathbf{C}$ in Fig. 6). 

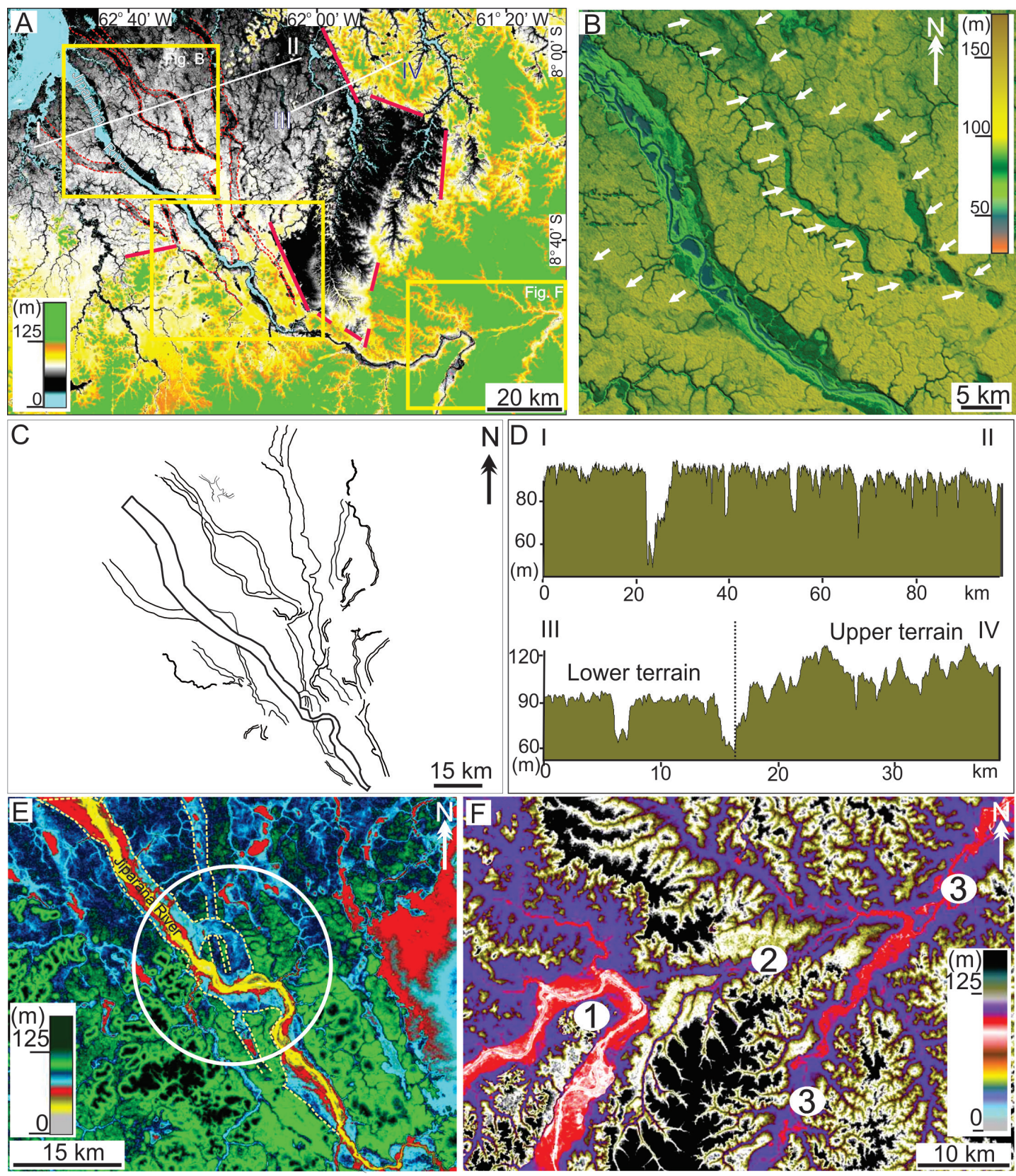

Figure 8 - Characterization of paleochannels in the Jiparaná area. A) DEM-SRTM data with general view of paleochannels (dashed red lines) on both sides of Jiparaná River (inside boxes locate figures $\mathbf{B}$, E, and most of $\mathbf{F}$; white lines I-II and III-IV locate topographic profiles shown in D; continuous red lines = straight morphostructural lineaments located at the boundary between the highest and the lowest terrain). B) DEM-SRTM data with a closeup of paleochannels (arrows) shown in the northwest part of A. C) Line drawing of the paleochannel network. D) Topographic profiles derived from DEM-SRTM (see location in A). E) DEM-SRTM data with a detail of A, illustrating the interception of an almost N-S trending paleochannel by a NW-SE paleochannel, where the modern Jiparaná River is entrenched (yellow dashed lines = paleochannels) (circle = interception point; dashed yellow lines = paleochannels). F) DEM-SRTM data with a detail of A, illustrating the location where the course of Jiparaná River (1) changes drastically from northeast to southwest, configuring a tight meander likely due to river capture. Note a paleovalley (2) that indicates the previous course of this river, today occupied by a northeast flowing tributary of the Roosevelt River (3). 
However, paleochannels are less abundant than in the Aripuanã-Marmelos area, being represented mainly by belts with lengths and widths up to 100 $\mathrm{km}$ and $3.6 \mathrm{~km}$, respectively. These features are slightly sinuous, mostly continuous, and represented exclusively by single belts arranged in a radial pattern (Fig. 8A-C). Similar to many of the AripuanãMarmelos paleochannels, the morphological relationships of the Jiparaná paleochannels attest that they are superposed upon one another, which results in a misleading impression of branching channels. Upstream, all paleochannels converge into an area where the Jiparaná River displays anomalous meanders (Fig. 8E). It is noteworthy that some of the paleochannels are superposed by the modern Jiparaná River, which in the study area is mostly straight to slightly sinuous. All paleochannels in the Jiparaná area occur northwest of the point where this river experiences an orthogonal inflection from northeast to northwest, which result in a wide and closed meander (Fig. $8 \mathrm{~F})$. At this location, a tributary of another river, the Roosevelt River, is entrenched within a NE-SW paleovalley connected to the Jiparaná River.

Morphostructural lineaments are similar throughout the study area independently of the geological substrate, as shown by the length and frequency diagrams presented in Fig. 9. The E-W orientation was the most common mode, followed by NE-SW and NW-SE orientations. $\mathrm{N}-\mathrm{S}$ orientation was expressive in the area corresponding to Precambrian basement rocks.

\section{DISCUSSION}

ChANNEl DyNAMics Over TIME

The observation of paleochannels in the AripuanãMarmelos and Jiparaná areas is not a novelty. Two previous publications (i.e., Mauro et al. 1978, Latrubesse 2002) provided general descriptions of these landforms. Additionally, other paleochannels were documented along the Madeira River upstream from the study area (Souza Filho et al. 1999).
However, our approach based on DEM-SRTM data allowed these paleochannels to be characterized in more detail. This is particularly true for paleochannels hidden under dense forest which were not detected by any other remote sensing products. The DEM-SRTM technology significantly enhanced the potential for paleochannel scrutiny, enabling a better understanding of their temporal relationships.

An observation of remarkable interest provided by the exceptional view of paleomorphologies revealed by DEM-SRTM was that most of the main paleochannels in both areas were not coeval in time. This is indicated by the intricate network of paleochannels that frequently superpose one another, rather than representing laterally coexisting drainage systems. Most likely, these features record single channels that occupied different locations over time. The reconstruction of the Aripuanã-Marmelos paleodrainage suggests the existence of two main north/northwest-trending tributary systems related to ancient courses of the Aripuanã and Roosevelt rivers (Fig. 10A). The convergence of these paleochannels in the central part of this study area resulted in them being interpreted as tributaries connected to a single trunk river that flowed into the Madeira River. Following a slight northwestward (Fig. 10B) migration, the Aripuanã paleoriver drastically changed into its modern northeast-trending course. As this process occurred, the Roosevelt River was captured by a north/ northeastward flowing river segment, which made the connection between this river and the Aripuanã River (Fig. 10C). Consequently, two long channel segments became abandoned to the west of the Aripuanã River (Fig. 10C). In addition, the central part of the study area became the headwater for many northwestward small draining basins (Fig. 10D) that were abandoned or are still in the process of abandonment. The numerous dendritic northeastward trending paleodrainage systems that occur between the lowest and highest terrains perhaps were possibly also abandoned during this period. 


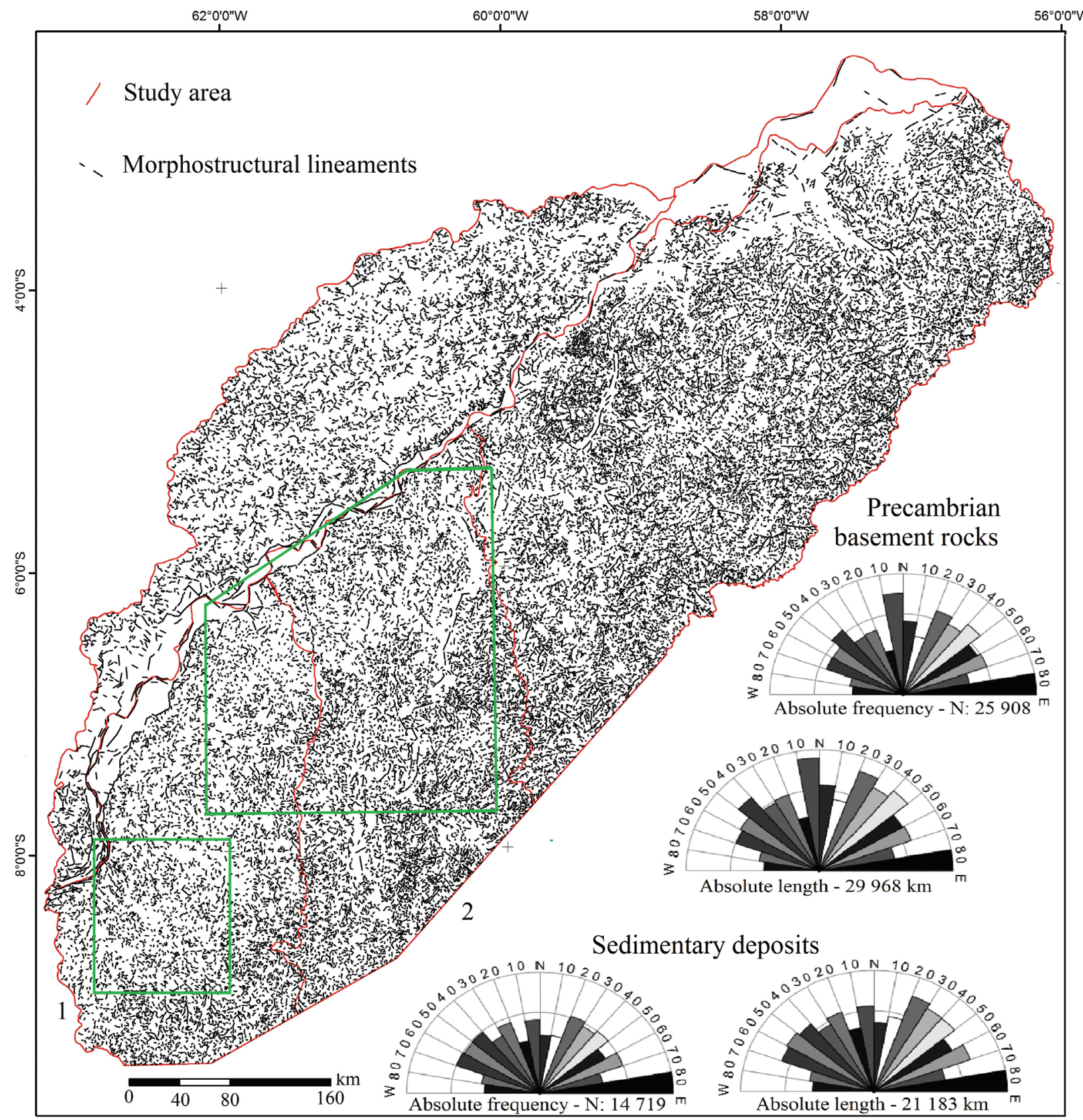

Figure 9 - Morphostructural lineaments from the study areas (indicated by the polygons) and its surroundings. Included rose diagrams shows lineament frequency and length from areas of Precambrian basement rocks and sedimentary deposits corresponding to the entire region.

Despite the less intricate network, the paleochannel dynamics in the Jiparaná area is not as well understood as those from the Aripuanã-Marmelos area. All the Jiparaná paleochannels have a common root with the downstream segment of the modern Jiparaná River. They spread out northwestward from this river following a radial pattern. For this reason, a preliminary impression is that these paleochannels record several distributaries. However, the DEMSRTM data did not provide any evidence to support a myriad of laterally coexisting channels typical of distributary systems. Instead, these 


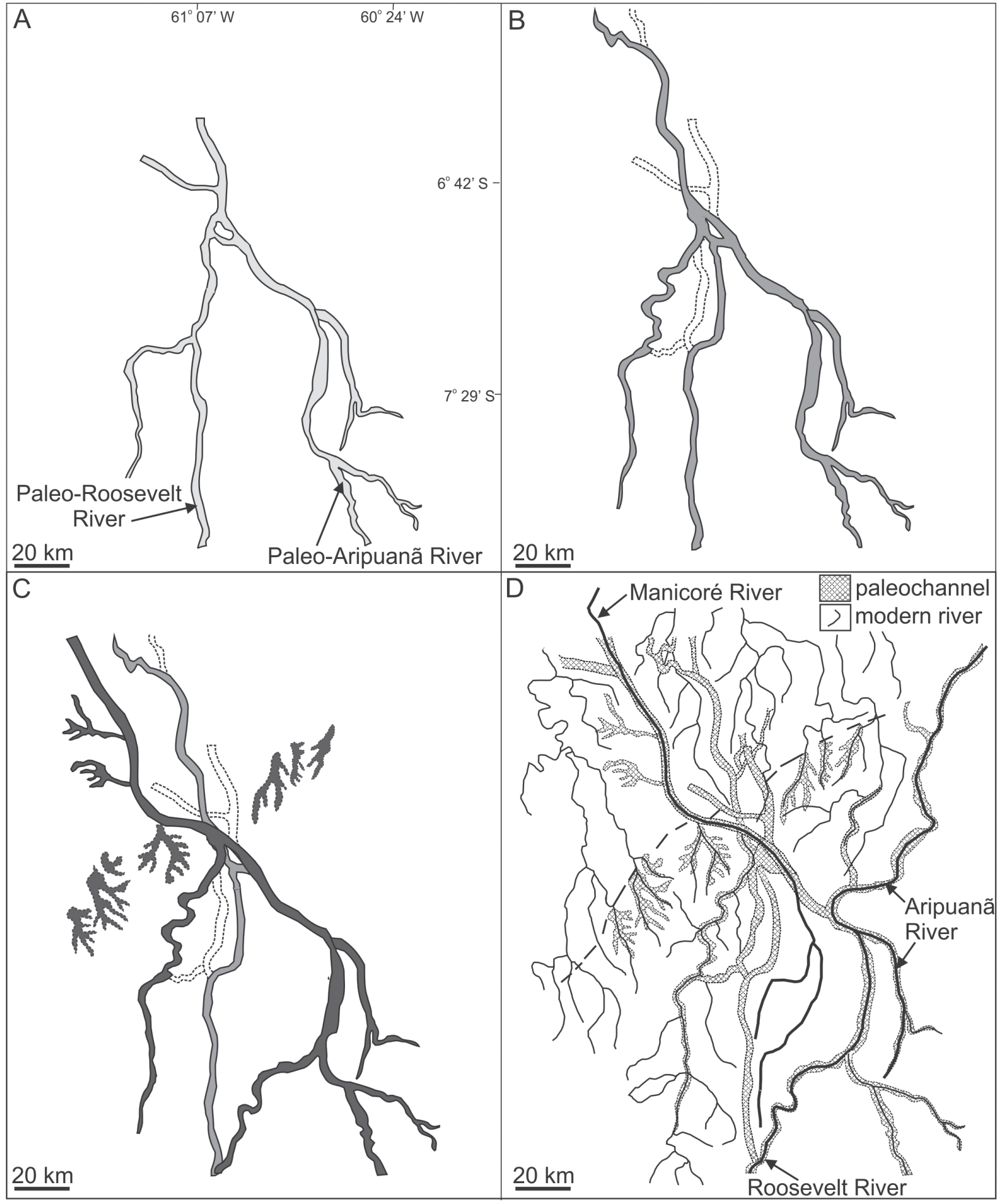

Figure 10 - A-D) Proposed drainage evolution in the Aripuanã-Marmelos area based on interpretation of paleochannel relationships derived from the DEM-SRTM. A set of avulsion episodes culminated with the dislocation of Aripuanã River from northwest to northeast. (Time increases from $\mathbf{A}$ to $\mathbf{D}$; dashed lines = paleochannels; straight lines in the center of the Fig. $\mathbf{D}=$ straight morphostructural lineaments between the higher and lower terrains). (See text for further explanation). 
paleochannels more likely record different positions occupied by a single channel, in this instance the lower Jiparaná River (Fig. 8C). Hence, the most probable hypothesis is that this river was located nearly $60 \mathrm{~km}$ eastward of its modern position (measured at the confluence with the Madeira River), when it drained northward. This river was then dislocated back and forth several times until it ended in its present northwest position. As migration took place, previously abandoned courses were progressively superposed by active channels. This dynamic evolution would have produced the radial paleodrainage network and the associated triangularshaped sedimentary succession.

\section{A Revisit to THE MEgafan Model}

Considering the preceding discussion of channel dynamics over time, the new data presented here can be used to review their previous attribution to megafan systems (cf. Latrubesse 2002, Wilkinson et al. 2010). Megafans are generally defined as depositional systems of great dimensions, i.e., $10^{3}-10^{5}$ $\mathrm{km}^{2}$ (DeCelles and Cavazza 1999) developed in areas of very low topography, i.e., $0.1^{\circ}$ to $0.01^{\circ}$ (Gohain and Parkash 1990, Sinha and Friend 1994, Leier et al. 2005) mostly under arid to semiarid climate (Gibling 2006). This type of depositional system produces large scale sediment deposition mainly by the development of multiple distributary channels (Friend 1978, Kelly and Olsen 1993, Nichols and Fisher 2007, Hartley et al. 2010, Weissmann et al. 2010). According to these authors, channels associated with megafans are either meandering or braided, and they may produce large amounts of unconfined fan-shaped deposits. This characteristic imposes an overall triangular morphology to the entire system.

Triangularorfan-shapeddepositsanddistributary channel patterns have generally been used to define megafans (e.g., Gumbricht et al. 2001, Stanistreet and McCarthy 1993, Sinha et al. 2005, Nichols and Fisher 2007, Chakraborty et al. 2010). Fan-shaped deposits and unequivocal features supporting multiple distributary networks were not identified in the study areas. As demonstrated above, the studied landforms are more consistent with a few channels that changed their course over time, rather than laterally coexisting, interconnecting distributary channels. In fact, many paleochannels supposedly related to distributary paleochannel networks actually result from successive avulsions of a single channel over time. The channel bifurcations of the Aripuanã-Marmelos area suggest downstream flow convergence, rather than a divergence as would be expected from distributary channels.

The conceptual model of fluvial distributaries has been used to characterize megafan systems since its introduction by Friend (1978). Such a model cannot be applied to support a megafan hypothesis for the study areas. Instead, the studied paleodrainage systems appear to correspond to a small number of tributaries that underwent avulsions and captures over time. Our interpretation is that this radial paleodrainage arrangement reflects dislocation of a few main tributaries of the Madeira River.

Our study of the Madeira paleomorphologies led to a re-evaluation of the use of the term megafan to refer to depositional systems. This term corresponds to an assemblage of genetically related lithofacies within a particular depositional environment, which is defined, in turn, as a geomorphic unit formed by laterally coexisting sub-environments. The study of depositional environments in the ancient record is, therefore, essentially the study of geomorphology, i.e., the recognition of geomorphic units where sediment deposition takes place (Reineck and Singh 1986). In the particular case of our study area, there is no evidence to support neither clearlydefined cone-morphologies with correspondence to geomorphic units, nor physical processes distinct from those related to fluvial systems. In addition to the absence of distributary channel networks, there is no indication of a convex-up fan morphology that may have induced channel shifting from one position to another. While paleochannels may 
be radially distributed (at least in the case of the Jiparaná area), they do not seem to be associated with fan-shaped deposits. On the contrary, the most likely interpretation is that the channel flows were never distributed as a consequence of a fan morphology. Hence, what most likely occurred was that as tributary channels shifted position along a flat-lying area, temporally distinctive fluvial sedimentary successions built up laterally or superposed upon one another in order to establish a sedimentary record (not a geomorphic unit!) with a triangular morphology in plan view.

The foregoing interpretation of the Madeira paleodrainage complexes is in agreement with observations from several other megafan analogs. For instance, the Kosi River fan, one of the most wellstudied megafan worldwide, was built by numerous avulsions (Mookerjea 1961, Gohain and Prakash 1990, Bridge 2003), with several shifts over time (Sinha 2009, Chakraborty et al. 2010). The modern channel of this river in the fan area displays an anastomosing pattern, and this occurs where avulsion channels rejoin the main stream (Slingerland and Smith 2004). Assuming this as a modern analog for the paleochannels recorded in that area, the fan as a whole may have been built through partial avulsions, instead of fully distributary channels radiating from a trunk river. Other distributary fluvial fans have been re-interpreted as depositional settings characterized by multiple avulsions of tributary channels, and not by downstream bifurcation of temporally coexisting channels (e.g., North and Warwick 2007, Bernal et al. 2011).

More than a simple matter of semantics, this issue is of great relevance when analyzing megafans and attempting to reconstruct their sedimentary record. Sedimentary lithofacies produced in megafans lacking true evidence of both distributary flows and associated unconfined fan deposits are compared to those lithofacies produced in fluvial environments with frequent avulsions, but not necessarily associated with plan view fan morphologies. The
DEM-SRTM topographic gradient suggests a northeastward-dipping terrain in the Aripuanã area and a nearly horizontal terrain over most of the Jiparaná area. In addition to the lack of evidence for distributary flows, the Jiparaná area does not show sedimentary successions with convex-up fan morphologies, as documented in typical megafans such as the Okavango (Gumbricht et al. 2001), the Taquari (Assine 2005), the Kosi (Chakraborty et al. 2010), and the Pastaza (Bernal et al. 2011). In part, this could mean that the fan morphology was cleared from the landscape after fan abandonment. However, the hypothesis that a convex-up fan morphology was never established in the study areas should not be ruled out. The preferred interpretation is that the radial paleodrainage morphology observed in remote sensing products in this instance is due to tributary channels that experienced avulsions over time.

\section{AvUlsion TRIGgER MECHANISM}

Avulsion is most often caused by rapid alluviation due to high sediment load transported into the main channel, when floodplain aggradation increases (Slingerland and Smith 2004). However, other causes may also exist, such as changes in flow discharge, topography, subsidence rate, drainage catchment size and channel gradient. Aggradation may be triggered by mechanisms intrinsic to the depositional environment, such as high floods, but frequent avulsions are more common in tectonicallyinfluenced geological settings (e.g., Schumm et al. 1996, Jones and Schumm 1999, Gumbricht et al. 2001, Assine 2005), and are particularly recorded in foreland basins (Horton and DeCelles 2001, Leier et al. 2005, Nichols and Fisher 2007).

Different proxies have been presented in support of dry climatic episodes during the Late Pleistocene in Amazonia (Absy et al. 1991, Webb and Rancy 1996, Behling et al. 1999, Pessenda et al. 2001, Sifeddine et al. 2001). The previously proposed megafans in the Madeira area were linked to dry climatic phases during the Last Glacial 
Maximum, with subsequent channel abandonment following stages of climate amelioration (Latrubesse 2002). This interpretation is valid only under two assumptions: (i) the paleodrainage networks are related to megafan morphologies; and (ii) megafans are indeed restricted to arid and semi-arid areas. In addition to data from modern humid to subhumid megafans (for instance, the Taquari megafan described by Assine 2005), the discussion presented herein leads us to argue that climate might have not been the main trigger of tributary channel avulsions recorded in the Madeira area.

Although a definitive interpretation will require further geological validation, a line of morphological evidence supports tectonics as the most plausible cause of channel avulsion in the Aripuanã-Marmelos and Jiparaná areas. Evidence that the Quaternary deposits in these areas were formed in a low-lying terrain due to fault subsidence includes: (i) its sharp contact with Precambrian to Cretaceous rocks defined by several NE-trending straight morphostructural lineaments; (ii) the matching of these lineaments with the abrupt narrowing of several large NW- to NE-trending paleochannels, which suggests changes in river courses due to terrain displacement; and (iii) the many drainage anomalies consisting of NEtrending orthogonal river inflections at the boundary between the lower and higher terrains. Additionally, tectonic tilting is indicated by the overall NEdipping DEM-SRTM topographic gradient of these terrains. This interpretation is consistent with both the dislocation of the Aripuanã River from a N/NWtrend to its modern northeast position (Fig. 8A-D) and the overall progressive northeastward development of avulsion channels. The wide loop coincident with the avulsion axis of the Aripuanã River constitutes a major drainage anomaly, further supporting tectonically-controlled river shifts. Furthermore, the abrupt orthogonal inflection of the modern lower course of the Jiparaná River from northeast to northwest (Figs. 1A, 3A), added to its association to a wide and tight meander, constitutes an important drainage anomaly further suggestive of tectonic influence. In this location, the entrenchment of the Roosevelt River's tributary within a paleovalley connected to the Jiparaná River indicates that the latter river ran northeastward before deviation to its modern northwest position. A previous regional investigation suggested that this river capture was due to tectonics (i.e., Mauro et al. 1978). Altogether, such morphological characteristics lead us to propose tectonics as the cause of successive shifts of the lower course of the Jiparaná River from northeast to northwest.

The morphological characteristics of the study areas do not constitute isolated features in support of a tectonic influence on the Amazonian lowlands during the late Quaternary. Many earlier publications have emphasized this issue. For instance, an early study recognized that the middle Amazon River is controlled by NE-SW and NW-SE trending faults (Sternberg 1950). The lower Negro River is likely a half-graben related to dextral E-W strike slip faults (Franzinelli and Igreja 1990), as well as nearly E-W and N-S trending structures (Franzinelli and Latrubesse 1993). More recently, it has been proposed that the current lower course of this river is driven by displacement along pre-existing NW-SE tectonic faults (Almeida Filho and Miranda 2007). A combination of NW-SE, NE-SW and E-W trending faults in the late Holocene influenced channel dynamics in the middle Amazon River (Latrubesse and Franzinelli 2002). Closer to the study areas, major river rearrangements in the Purus basin were related to tectonic subsidence (Pimienta 1958, Saadi 1993). Additionally, the activity of pre-existing faults would have promoted the southeastward dislocation of a nearly $200 \mathrm{~km}$ long segment of the Madeira River, as well as many associated drainage anomalies immediately northwestward of the study area (Hayakawa et al. 2010). Channel abandonment reported in the upper Madeira River was related to tilting caused by tectonic reactivation of NW-SE and NE-SW transform faults (Souza Filho et al. 
1999). Numerous other studies have also suggested tectonics as the most significant control of ancient and modern river development in Amazonian areas (e.g., Mauro et al. 1978, Bemerguy and Costa 1991, Latrubesse and Rancy 2000, Costa et al. 1995, 2001, Fernandes Filho et al. 1997, Nogueira and Sarges 2001, Franzinelli and Igreja 2002, E.A.A. Soares, unpublished data, Rossetti et al. 2007, 2012a, b, see also several references in Mertes and Dunne 2007). A recent publication has demonstrated that the development of fluvial terraces along the Madeira River occurred under the influence of tectonics (Rossetti et al. 2013). The extensive documentation of tectonic influences on Amazonian rivers is also consistent with modern seismogenic data from this region, where earthquakes of high magnitudes (up to 8) have been recorded (Assumpção and Suárez 1988, França 2006).

The predominant orientation of the morphostructural lineaments in the study area (see Fig. 9) is in agreement with Precambrian shear zones defined regionally in the Amazon Craton (Costa et al. 1996). These shear zones were reactivated during the Neogene-Quaternary, and also affected sedimentation in the Holocene (F.H.R. Bezerra, unpublished data). These, together with the data presented herein, support a tectonically unstable Amazonian lowland during the Quaternary, with a direct consequence on the evolution of its river systems.

\section{CONCLUSIONS}

The DEM-SRTM constitutes an important tool to improve the characterization of paleodrainage networks in forested areas of Amazonia. This type of data was fundamental to analyze the Madeira paleodrainage networks, allowing us to propose a comprehensive model that can explain channel dynamics during the late Quaternary. The complex sets of paleochannels present in this area were attributed to successive avulsions of a small number of channels over time. The radial distribution of the studied paleochannel systems in plan-view resembles distributary networks related to megafans. However, the studied deposits do not contain evidence of distributary channels, or of their association with convex-up depositional environments as typical of megafans. The present study reveals that large tributary fluvial systems subjected to avulsions can be equivocally interpreted as distributary megafans. In both cases, the resulting deposits display fan shapes associated with radial paleodrainage networks. Considering a megafan model for the study areas, this would be characterized by multiple avulsions of tributary channels within a given time scale, rather than by downstream bifurcation of temporally coexisting channels. Such characteristic does not conform to megafan models. The morphological characteristics of the study area indicate to tectonics as an important mechanism leading to channel shifting. Therefore, rather than climate fluctuations associated with glacial/interglacial episodes, we propose that channel shifting over time and the resulting complex networks of radially distributed paleochannels were promoted by fault reactivation.

\section{ACKNOWLEDGMENTS}

The authors acknowledge the Conselho Nacional de Desenvolvimento Científico e Tecnológico (CNPq) for a doctoral scholarship and a research fellowship (project \# 471483/06-0). The Instituto Nacional de Pesquisas Espaciais (INPE) provided the computational resources needed for processing remote sensing data. We also wish to thank the Brazilian Geological Survey-CPRM and the $54^{\text {th }}$ Jungle Infantry Battalion of the Brazilian Army for logistical support during fieldwork.

\section{RESUMO}

Sistemas de drenagem antigos têm sido documentados na bacia do Amazonas e sua caracterização é crucial para a reconstrução da evolução fluvial nessa área. Morfologias fluviais, incluindo cinturões alongados, são bem preservadas ao longo do rio Madeira. O modelo 
digital de elevação do Shuttle Radar Topography Mission (SRTM) favoreceu a detecção dessas feições até mesmo em áreas cobertas por vegetação florestal densa. Essas paleomorfologias são atribuídas a mudanças de posição de antigos tributários do rio Madeira por meio de avulsões. Essas redes de paleodrenagens radiais produziram morfologias em leque que lembram megaleques distributários. A distinção entre sistemas tributários avulsivos e megaleques distributários no registro sedimentar é um desafio. A paleodrenagem do Madeira revela a superposição de canais tributários formados por avulsões múltiplas dentro de um dado período de tempo, mais do que a bifurcação a jusante de canais coexistentes. A avulsão de canal nessa área Amazônica durante o Quaternário tardio é relacionada à tectônica devido a feições como: (i) lineamentos retilíneos coincidentes com direções de falhas; (ii) mergulho para nordeste dos terreno com estratos quaternários; e (iii) várias anomalias de drenagem, incluindo inflexões ortogonais de drenagem. Essas características em conjunto levam a propor que a paleodrenagem radial presente nas margens do rio Madeira resulta de avulsões sucessivas de canais tributários ao longo do tempo devido à tectônica.

Palavras-chave: paleocanais, Bacia Amazônica, rio Madeira, sensoriamento remoto, clima, tectônica.

\section{REFERENCES}

Absy ML, Cleef A, Fournier M, Martin L, Servant M, Siffedine A, Silva MFF, Soubies F, Suguiu K, TurCQ B AND VAN Der HAMmen T. 1991. Mise en évidence de quatre phases d'ouverture de la forêt dense dans le sudest de l'Amazonie au cours des 60000 dernière années. Première comparison avec d'autres régions tropicales. Compte Rendus l'Acad Sci 312: 673-678.

AlmeidA Filho R AND MiRANDA FP. 2007. Mega capture of the Rio Negro and formation of the Anavilhanas Archipelago, Central Amazônia, Brazil: evidences in na SRTM digital elevation model. Rem Sens Env 10: 387-392.

Apoluceno Neto AF And Tsubone K. 1988. A descoberta de petróleo do Rio Urucu, Bacia do Solimões. In: Congr Bras Geol, 2, 1988. Belém, Brasil. Proceedings...Belém: Soc Bras Geol 6: 2416-2427.

Assine ML. 2005. River avulsions on the Taquari megafan, Pantanal wetland, Brazil. Geomorphology 70: 357-371.

ASSUMPÇÃo M AND SUÁREZ G. 1988. Source mechanisms of moderate-size earthquakes and stress orientation in midplate South America. Geophys J 92: 253-267.
Behling H, Berrio JC And HoOghiemstra H. 1999. Late Quaternary pollen records from the middle Caquetá river basin in central Colombian Amazon. Palaeogeogr Palaeoclimatol Palaeoecol 145: 193-213.

BEMERGUY RL AND Costa JBS. 1991. Considerações sobre a evolução do sistema de drenagem da Amazônia e sua relação com o arcabouço tectônico-estrutural. Bol Mus Paraense Emílio Goeldi 3: 77-98.

Bernal C, Christophoul F, Darrozes J, Soula J-C AND Burgos PB. 2011. Late Glacial and Holocene avulsions of the Rio Pastaza Megafan (Ecuador-Peru): frequency and controlling factors. Int J Earth Sci 100: 1759-1782.

Bertani TC, Rossetti DF AND AlbUQUerque PCG. 2013. Object-based classification of vegetation and terrain topography in southwestern Amazonia (Brazil) as a tool for detecting ancient fluvial geomorphic features. Comp Geosci 60: 41-50.

BRIDGE JS. 2003. Rivers and floodplains: forms, processes and sedimentary record. Blackwell Science Ltd, Oxford 204 p.

CAPUTO MV AND SILVA OB. 1990. Sedimentação e tectônica da Bacia do Solimões. In: RAJA GABAGLIA GP and MILANI EJ (Eds), Origem e evolução de bacias sedimentares. Petrobras, Rio de Janeiro, p. 169-191.

Chakraborty T, Kar R, GHosh P AND Basu S. 2010. Kosi megafan: historical record, geomorphology and the recent avulsion of the Kosi River. Quat Int 227: 143-160.

COSTA JBS, BEMERGUY RL, HASUI Y AND BORGES MS. 2001. Tectonics and paleogeography along the Amazon River. South Am Earth Sci 14: 335-347.

Costa JBS, Hasui Y, Borges MS And Bemerguy, RL. 1995. Arcabouço tectônico Mesozóico-Cenozóico da região da calha do rio Amazonas. Geociências 14: 77-103.

Cunha PRC, Gonzaga FG, Coutinho LFC AND FeIJó FJ. 1994. Bacia do Amazonas. Bol Geocienc Petrobras 8: 47-55.

DAEMON RF. 1975. Contribuição para a datação da Formação Alter do Chão, Bacia do Amazonas. Rev Bras Geocienc 5: 78-84.

DECELLES PG AND CAVAZZA W. 1999. A comparison of fluvial megafans in the Cordilleran (Upper Cretaceous) and modern Himalayan foreland basin systems. Geol Soc Am Bull 111: 1315-1334.

Fernandes Filho LA, Costa ML and Costa JBS. 1997. Registros neotectônicos nos lateritos de Manaus Amazonas. Geociências 16: 9-33.

FrANÇA GS. 2006. Brazil seismicity. Bull Int Inst Seismol Earthquake Eng 40: 23-36.

FRANZINELLi E AND IGREJA HLS. 1990. Utilização de sensoriamento remoto na investigação na área do Baixo rio Negro e Grande Manaus. In: Simp Bras Sens Rem, 6, 1990. Manaus, Brazil. Proceedings...Manaus: Soc Bras Geol 3: 641-648.

FrANZINELli E AND IGREJA H. 2002. Modern sedimentation in the Lower Negro River, Amazonas State, Brazil. Geomorphology 44: 259-271.

FRANZINELli E AND LATRUBESSE E. 1993. The use of remote sensing in a neotectonic study in the Amazon Basin. Bull INQUA 16: 10-13. 
FRIEND PF. 1978. Distinctive features of some ancient river systems. In: Miall AD (Ed), Fluvial Sedimentology. Can Soc Petr Geol Memoir 5: 531-541.

FRIEND PF. 1989. Space and time analysis of river systems, illustrated by Miocene systems of the northern Ebro Basin in Aragon, Spain. Rev Soc Geol España 2: 55-64.

FRIEND PF AND MOODY-STUART M. 1972. Sedimentation of the Wood Bay Formation (Devonian) of Spitsbergen: regional analysis of a late orgenic basin. Norsk Polar Inst Skrifter 157, Oslo, $77 \mathrm{p}$.

GIBLING MR. 2006. Width and thickness of fluvial channel bodies and valley fills in the geological record: a literature compilation and classification. J Sed Res 76: 731-770.

GIBBS RJ. 1967. The geochemistry of the Amazon River system; part. I. The factors that control the salinity and the composition and concentration of the suspended solids. Geol Soc Am Bull 78: 1203-1232.

GOHAIN K AND PARKASH B. 1990. Morphology of the Kosi megagan. In: RACHOCKI AH and CHURCH M (Eds), Alluvial Fans, Wiley \& Sons, London, p.151-178.

Gumbricht T, McCARThy T AND Merry C. 2001. The Topography of the Okavango Delta, Botswana, and its sedimentological and tectonic implications. South Afric J Geol 104: 243-264.

Hartley AJ, Weissmann GS, Nichols GJ AND WARWICK GL. 2010. Large distributive fluvial systems: characteristic and controls on development. J Sed Res 80: 167-183.

HAYAKAWA EH, ROSSETTI DF AND VALERIANO MM. 2010. Applying DEM-SRTM for reconstructing a late Quaternary paleodrainage in Amazonia. Earth and Plan Sci Lett 297: 262-270

Horton BK AND DeCelles PG. 2001. Modern and ancient fluvial megafans in the foreland basin system of the central Andes, southern Bolivia: Implications for drainage network evolution in fold-thrust belts. Basin Res 13: 43-61.

HOWARD AD. 1967. Drainage analysis in geologic interpretation: A summation. Amer Assoc Petrol Geol Bull 51: 2246-2259.

IRION G. 1984. Sedimentation and sediments of Amazonian rivers and evolution of the Amazonian landscape since Pliocene times. In: SIOLI H (Ed), The Amazon limnology and landscape ecology of a mighty tropical river and its basin. Junk Publishers, Dordbrecht, p. 201-214.

IRIONDO M AND SUGUIO K. 1981. Neotectonics of the Amazon plain. Bull INQUA Neotect Commission 4: 72-78.

JONES LS AND SCHUMM SA. 1999. Causes of avulsion: an overview. In: SMITH ND and ROGERS J (Eds), Fluvial sedimentology. Blackwell Science, Spec Publ Int Assoc Sed, n. 28, Oxford, p. 171-178.

Kelly SB AND OLSEN H. 1993. Terminal fans: a review with reference to Devonian examples. Sed Geol 85: 339-374.

LATRUBESSE EM. 2002. Evidence of Quaternary palaeohydrological changes in middle Amazônia: The AripuanãRoosevelt and Jiparaná "fans". Z Geomorph NF129: 61-72.

LATRUBESSE EM. 2008. Patterns of Anabranching channels: the ultimate end-member adjustments of mega-rivers. Geomorphology 101: 130-145.
LATRUBESSE EM AND FRANZINELLI E. 2002. The Holocene alluvial plain of the middle Amazon River, Brazil. Geomorphology 44: 241-257.

LATRUBesse EM AND RAMONELl C. 1994. A Climatic Model for Southwestern Amazonia at Last Glacial times. Quat Int 21: 163-169.

LATRUBESSE EM AND RANCY A. 2000. Neotectonic influence on tropical rivers of southwestern Amazon during the late Quaternary: the Moa an Ipixuna river basins, Brazil. Quat Int 72: 67-72.

Latrubesse EM, Stevaux JC AND Sinha R. 2005. Tropical Rivers. Geomorphology 70: 187-206.

Leier AL, DeCElles PG AND Pelletier JD. 2005. Mountains, monsoons and megafans. Geology 33: 289-292.

Mantelli LR, Rossetti DF, AlbuQuerque PG AND VALERIANO MM. 2009. Applying SRTM digital elevation model to unravel Quaternary drainage in forested areas in northeastearn Amazonia. Comp Geosci 35: 2331-2337.

MAURo CA, NunES BTA AND FRANCO MSM. 1978. Geomorfologia-Folha SB 20 Purus. RADAMBRASIL, DNPM, Rio de Janeiro.

MERTES LAK AND DUNNE T. 2007. Effects of tectonism, climate change and sea level change on the form and behaviour of the modern Amazon River and its floodplain. In: GUPTA A (Ed), Large rivers: geomorphology and management. J Wiley \& Sons, United Kingdon, p. 115-144.

MoNsCH KA. 1998. Miocene fish faunas from the northwestern Amazonian basin (Colombia, Peru, Brazil) with evidence of marine incursions. Palaeogeogr Palaeoclimat Palaeoecol 143: 31-50.

MoOKERJEA D. 1961. The Kosi-a challenge in river control. Journal of the Institution of Engineers (India) 42: 117-142.

Müller J, Irion G, Mello JN AND JunK W. 1995. Hydrological changes of the Amazon during the Last Glacial-Interglacial Cycle in Central Amazonia (Brazil). Naturwissenschaften 82: 232-235.

Nichols GL AND Fisher JA. 2007. Processes, facies and architecture of fluvial distributary system deposits. Sed Geol 195: 75-90.

NOGUEIRA ACR AND SARGES RR. 2001. Characterization and genesis of waterfalls of the Presidente Figueiredo region, northeast State of Amazonas, Brazil. An Acad Bras Ciênc 73: 287-301.

NORTH CP AND WARWICK GL. 2007. Fluvial fans: myths, misconceptions and the end of the terminal fan model. J Sed Res 77: 693-701.

Pessenda lCR, Boulet R, Aravena R, Rosolen V, Gouveia SEM, RIBEIRO AS AND LAMOTTE M. 2001. Origin and dynamics of soil organic matter and vegetation changes during the Holocene in a Forest-savanna transition zone, Brazilian Amazon region. Holocene 11: 250-254.

PIMIENTA J. 1958. Modifications climatiques et subsidence récent affectant le glacis sud du Bassin de l' Amazone. CR Acad Sci 246: 2268-2271.

ReINECK HE AND SINGH IB. 1986. Depositional Sedimentary Environments, $2^{\text {nd }}$ ed., Springer-Verlag Berlin, 579 p. 
RossetTI DF. 2010. Multiple remote sensing techniques as a tool for reconstructing late Quaternary drainage in the Amazon lowland. Earth Surf Proc Landf 35: 1234-1239.

Rossetti DF, BERTANI TC, ZANI H, CREMON EH AND HAYAKAWA EH. 2012b. Late Quaternary sedimentary dynamics in Western Amazonia: Implications for the origin of open vegetation/forest contrasts. Geomorphology 177: 74-92.

Rossetti DF, COHEn MCL, BERTANi TC, HAYAKAWA EH, PAZ JDS, CASTRO DF AND FRIAES Y. 2013. Late Quaternary fluvial terrace evolution in the main southern Amazonian tributary. Catena 116: 19-37.

RossetTi DF AND NeTTo RG. 2006. First Evidence of Marine Influence in the Cretaceous of the Amazonas Basin, Brazil. Cret Res 27: 513-528.

Rossetti DF, Toledo PM AND Góes AM. 2005. New geological framework for Western Amazonia (Brazil) and implications for biogeography and evolution. Quat Res 63: 78-89.

RossetTI DF AND VALERIANO MM. 2007. Evolution of the lowest Amazon basin modeled from the integration of geological and SRTM topographic data. Catena 70: 253-265.

Rossetti DF, VALERIANO MM AND THALLÊS M. 2007. An abandoned estuary within Marajó Island: implications for Late Quaternary paleogeography of northern Brazil. J Est Coasts 30: 813-826.

RossetTI DF, ZANI H, COHEN MCL AND CREMON ÉH. 2012a. A Late Pleistocene-Holocene wetland megafan in the Brazilian Amazonia. Sedim Geol 281: 50-68.

SAADI A. 1993. Neotectônica da Plataforma Brasileira: esboço e interpretação preliminares. Rev Bras Geocienc 1: 1-15.

Schumm SA, DumONT JF AND HolbrooK JM. 2000. Active tectonics and alluvial rivers. Cambridge Univ Press, Melborne, $276 \mathrm{p}$.

SCHUMM SA, ERSKINE WDAND TILLEARD J. 1996. Morphology, hydrology and evolution of the anastomosing Ovens and King Rivers, Australia. Geol Soc Am Bull 108: 1212-1224.

Sifeddine A, MARTIN L, TURCQ B, VolkMER-Ribeiro C, Soubiès F, Cordeiro RC AND Suguio K. 2001. Variations of the Amazonian rainforest environment: a sedimentological record covering 30,000 years. Palaeogeogr Palaeoclimat Palaeoecol 168: 221-235.

Silva CL, Morales N, CRÓsta AP, Costa SS AND RuEdA JRJ. 2007. Analysis of tectonic-controlled fluvial morphology and sedimentary processes of the western Amazon basin: an approach using satellite images and digital elevation model. An Acad Bras Cienc 79: 693-711.

SinHA R. 2009. The Great avulsion of Kosi on 18 August 2008. Current Science 97: 429-433.

SINHA R AND FRIEND PF. 1994. River systems and their sediment flux, Indo-Gangetic plains, Northern Bihar, India. Sedimentology 41: 825-845.
SINHA R, GIBling MR, JAIN V AND TANDON SK. 2005. Sedimentology and avulsion patterns of the anabranching Baghmati River in the Himalayan foreland basin, India. Spec Pub Int Assoc Sed 35: 181-196.

Sioli H. 1984. The Amazon and its main afluentes: Hydrography, morphology of the Rivers courses, and river types. In: SIOLI H (Ed), The Amazon: limnology and landscape ecology of a might tropical river and its basin. Junk Publishers, Netherlands, p. 127-166.

SLINGERLAND R AND SMITH ND. 2004. River avulsions and their deposits. Ann Rev Earth and Plan Sci 32: 257-285.

SOUZA FILHO PWM, QUADROS MLES, SCANDOLARA JE, FILHO EPS AND REIS MR. 1999. Compartimentação morfoestrutural e neotectônica do sistema fluvial Guaporé-Mamoré-Alto Madeira, Rondônia, Brasil. Rev Bras Geocienc 29: 469-476.

STANISTREET IG AND MCCARTHY TS. 1993. The Okavango Fan and the classification of subaerial fan systems. Sed Geol 8: 115-133.

STERNBERG HO. 1950. Vales tectônicos na planície amazônica? Rev Bras Geog 4: 511-531.

TEIXEIRA W, TASSINARI CCG, CORDANI UG AND KAWASHITA K. 1989. A review of the geochronology of the Amazonianian Craton: tectonic implications. Precamb Res 42: 213-27.

Vital H AND Stattegger K. 2000. Lowermost Amazon River: evidence of late Quaternary sea-level fluctuations in a complex hydrodynamic system. Quat Int 72: 53-60.

WeBB SD AND RANCY A. 1996. Late Cenozoic evolution of the Neotropical mammal fauna. In: JACKSON J, BUDD $\mathrm{N}$ and COATES A (Eds), Evolution and Environments in Tropical America. University of Chicago Press, Chicago, p. 335-411.

WeissmanN GS, HaRtLey AJ, Nichols GJ, ScUderi LA, OLSON M, BUEHLER H AND BANTEAH R. 2010. Fluvial form in modern continental sedimentary basins: Distributive fluvial systems. Geology 38: 39-42.

Wesslingh FP, RÄSÄNEN ME, IrION G, Vonhof HB, KAANDORP R, RENEMA W, ROMERO-PITTMAN L AND GINGRAS M. 2001. Lake Pebas: a palaeoecological reconstruction of a Miocene long-lived lake complex in western Amazonia. Cainoz Res 1: 35-81.

Wilkinson MJ, MARSHALl LG, LUNDBERG JG AND KRESLAVSKY MH. 2010. Megafan environments in northern South America and their impact on Amazon Neogene aquatic ecosystems. In: HOORN $\mathrm{C}$ and WESSELINGH FP (Eds), Amazonia: landscape and species evolution. Blackwell Publishing, Malasia, p. 162-184.

WiLLIAMS EA. 2000. Flexural cantilever models of extensional subsidence in the Munster Basin (SW Ireland) and Old Red Sandstone fluvial dispersal systems. In: FRIEND PF and WILLIAMS PJ (Eds), New perspectives on the Old Red Sandstone. Geol Soc London Spec Publ 180: 239-268. 
